\title{
Understanding Consumer Characteristics in an Online Tourism Community in India
}

\author{
Nidhi Phutela, Hirak Dasgupta \\ Research Scholar, Lovely Professional University, Punjab \\ nidhiphutela@gmail.com \\ Director, Balaji Institute of Modern Management, Pune \\ hirak20@yahoo.com
}

\begin{abstract}
Analysing customer perceptions is an important requirement not only for offline stores, but for online stores as well. Study of customer perceptions helps the company in understanding the requirements and expectations of the customers in a better way. This study is an extension of the researcher's previous study of identifying antecedents of consumer trust for e-tourism companies in India. This study tries to explore the relationship between factors that build trust of the consumers on the online companies and their satisfaction level. Apart from studying the preferences and expectations of the consumers from e-tourism companies in India, the researcher has also tried to study the customer perceptions in context of online shopping in general. Data was collected by the researcher from 367 tourists (customers) who plan their tours online in Delhi NCR. Hypothesis testing has been done by using ANOVA and t-test. Findings of the study revealed that that amongst seven Consumer Trust dimensions, only "Promotional deals" and "Price Competitiveness" have a significant positive impact on "Customer Satisfaction", whereas the impact of other five variables are not significant.
\end{abstract}

\section{Indexing terms/Keywords}

consumer trust, customer satisfaction, e-tourism, online shopping, shopping orientation.

\section{Academic Discipline And Sub-Disciplines}

Management, Marketing, e-Tourism

\section{SUBJECT CLASSIFICATION}

Consumer Behaviour

\section{TYPE (METHOD/APPROACH)}

\author{
Survey Method, ANOVA
}

\section{INTRODUCTION}

In recent years, an increasing number of firms have entered the virtual world. The advent of e-commerce has laid a new foundation in the consumer market. Exposure of the company widens to a larger audience thereby increasing the challenge of attracting the right audience with good marketing strategies. Understanding consumer behaviour remains the foremost priority of the company being it an online or an offline store. Analysis of customer perceptions helps in segmenting the market and at the same time targeting the right audience.

Increased world-wide exposure has raised the competitiveness of the firms with the enhanced pressure of attracting more and more customers. The use of internet for the purpose of communicating and transacting with customers has been growing rapidly in the worldwide tourism industry (Sahadev \& Islam, 2005). As consumers continue to use the web for travel and hospitality resources, there is a need to examine the business-to-consumer online environment and the issues facing the continued acceptance and use of web by the consumers. Even the inclination of tourism industry is towards the understanding of the customer needs, preferences and behaviour, like all industries.

The internet usage also varies across countries, even within a country there are large variations among different enterprises. Despite the increasing number of internet users and forecasting the future prospects of online travel industry, practitioners have encountered problems and challenges, including how to attract and retain more \& more customers. There are no statistics showing the exact number of travellers who have purchased travel-related products online. It is apparent that not all online users make their purchases online. There is a quick need for finding as to who are the actual internet users and also they prefer to purchase or shop online.

This research work has been undertaken with an objective of studying the relationship between consumer trust and customer satisfaction, the impact of demographic variables on shopping orientations of the consumer and customer's perception about online shopping in the Indian market.

\section{LITERATURE REVIEW}

Each and every person is unique in himself/ herself. They have certain beliefs and values, which generally do not change easily. To attract and retain the customers, a company must first understand them. It also helps in incurrence of less 
hternational Journal of Management and Information Techonology expenditure. Understanding consumer behaviour for an online environment is a critical element for the success of any and every type of organization, which is perfectly achieved via understanding its customers in the exact sense what they want. In this study, consumer characteristics have been studied in terms of behaviour of the customers in response to online shopping in general. Customers with similar tastes and preferences can be clustered together for deriving good results. Hence, it is highly important for a company to understand customer's perception as unless the company is clear as to how their customers perceive them, it becomes really tough for the company to excel in their business. Relevance of the same can be studied in the following reviews of previous researches:

\section{Customer Perception}

Bajs (2011) propounded that perception of value is governed not only by perceived quality and costs but also by the product and service attributes. And, from among a whole set of different attributes, customer evaluates only a few of them. Kim, Park and Schwarz (2010) undertook a research on how the consumer evaluates the product via considering their emotions. It is so because mostly the decisions are based on hedonic predictions - will it be good for me to do this? They detailed that products making emotional claims may focus on hedonic predictions on the experiences brought to mind by the product claims - will the product make me feel the way it promises? Therefore, marketers can facilitate the impression that the product will deliver on its promises i.e. matching the product's claims with those of consumers' pre-existing feelings. Hallem and Barth (2011) investigated that better understanding of the needs of the medical tourists can help the marketers in better guiding of tourists and also taking good marketing decisions. Nysveen, Methlie and Pedersen (2003) presented a report on the value added services offered by tourism websites and which of those are important for the customers. The results indicated that study of customer preferences are of vital significance for deriving satisfaction and long term association with website. Shim et al. (2001) identified the importance of customer's intention to search the internet for product information. It is a key element for marketing researchers in predicting consumers' internet purchasing intentions. Results revealed that an intention to search internet for product information leads to an intention to purchase through the same medium; hence it should be considered important. It also exposed that intention to use internet for product information search acts as a central mechanism through which consumer characteristics affect higher-order decision making goals.

\section{Shopping Orientation}

Shopping orientations are related to general predisposition toward acts of shopping. They are conceptualised as a specific dimension of lifestyle and are operationalized on the basis of activities, interests and opinion statements pertaining to acts of shopping (Li et al., 2006). Classification of the consumers on the basis of acts of shopping is useful for the companies to target the consumers. Many research works have been undertaken by various researchers to identify the shopping orientations of consumers. Following are the briefings of such research works. As identified by Stone (1954), there are four types of shopping orientations namely: economic, personalizing, ethical and apathetic whereas Korgaonkar (1981) examined six groups of shoppers: recreational shopper, brand-loyal shopper, store-loyal shopper, price-oriented shopper, psych-socializing shopper and time-oriented shopper. Lumpkin (1985) in his research work studied elderly customers and identified three different segments - uninvolved shopper, inflation - conscious shopper and actively, highly involved shopper. Some specific researches were also conducted for specified products like that undertaken by Furse et al. (1982) for automobiles. They developed four types of shopper typologies namely constructive shoppers (who work hard for gathering information), surrogate shoppers (depend heavily on others for information search), preparatory shoppers (depend more on others reviews) and routinized shoppers (spend relatively less time on information search but exhibit brand loyalty). Apart from these offline stores, surveys were also conducted to analyze shoppers' orientations for online stores. Findings are mixed regarding consumer characteristics. An examination revealed that the shoppers are younger, venturesome and recreational; while others consider them to be thrifty innovators and focusing on time management. But, the fact is online stores also attract a set of customers with certain common attributes. Likewise, a study conducted by Greenfield Online (1999) identified that convenience and time saving feature of internet has motivated a certain set of customers to prefer online shopping than in-store shopping. Also the customers responded that malls allow them to see, feel, touch and try on the products before they buy them. This means that those consumers who prefer experiencing products are less likely to buy online. Also, Alba et al. (1997) stated that new entrants in the electronic commerce have adopted a policy to attract customers and build a brand name to earn long-term profits rather than focusing on short-term gains. That is, some customers may also go for online shopping due to reasonable prices offered by them. Online shopping has its own features and also attracts a certain set of customers. To understand the customer psychology is important for analyzing the target audience for these online companies. Positive attitude towards a particular thing can attract attention towards the same while negative attitude on the other hand can lead to avoidance of that thing.

\section{Attitude Towards Online Shopping}

Consumers who are more net savvy and have a good amount of exposure to internet can be more prone to online shopping. As stated by Fishbein \& Ajzen (1975), study of attitude towards online shopping is significant to understand the characteristics of an online consumer. This argument was further supported by Chen (2006). Risk is one important parameter which arouses or leads to avoidance of an action. When a person perceives risk in certain phenomenon, they not only avoid themselves, but they also motivate others to do the same. As considered by Shim et al. (2001), perceived risk of shopping online must be evaluated in context of past purchase experience with non-traditional means. This concept is an important criterion to analyze the customers' acceptability to online shopping in general. It will help the companies to identify the loopholes of why the consumers prefer online shopping less than the other mode of shopping. This study will be undertaken in two parts whereby the Part I deal with analyzing the characteristics of the consumers. This will make it easier for the online companies to segment the market and target right audience for increased sales.

2674 | P a g e

council for Innovative Research 


\section{Customer Satisfaction}

Customer satisfaction reflects the degree to which a consumer believes that the possession or use of a service evokes positive feelings as suggested by Rust \& Oliver (1994). It is evaluated as the psychological reaction of the customer with respect to his or her prior experience with the comparison between expected and perceived performance (Chang et al., 2009). Studies undertaken by Flavian et al, 2006; Bauernfeind and Zins, 2006; Brown et al., 2007; Heskett, 2008; Huh \& Shin, 2009; Wen, 2010; Lertwarinawit and Gulid, 2011; Walsh, Lynch and Harrington, 2011 and Phelan, 2011 revealed positive correlation of different factors of trust with customer satisfaction and loyalty. This study explores the same in Indian context as to which factors of trust increase more satisfaction amongst the customers.

\section{CONCEPTUAL FRAMEWORK OF THE STUDY}

Resultant of the literature of the previous studies helps in defining customer satisfaction as positive feelings of the customer towards the company because of fulfilled expectations. That means, if the expectations of the consumers are not met, it will end up in customer dissatisfaction. Studies further reveal that there is a positive correlation between consumer trust and customer satisfaction. To conclude, consumer's trust in a website increases their satisfaction level and promotes loyalty towards the company. This study also proposes the similar hypothesis in context of Indian environment. It will also help to identify the most crucial reasons for not only building trust, but also increasing the satisfaction level of the customers.

$\mathrm{H1}$ : Consumer Trust has no significant impact on Customer Satisfaction.

To test the above hypothesis, the impact of seven constructs of Consumer Trust (resultant of factor analysis) on Customer Satisfaction has been studied.

H1A: Website Characteristics has no significant impact on Customer Satisfaction.

H1B: Personalization has no significant impact on Customer Satisfaction.

H1C: Website Information has no significant impact on Customer Satisfaction.

H1D: Promotional deals have no significant impact on Customer Satisfaction.

H1E: Availability has no significant impact on Customer Satisfaction.

H1F: Price Competitiveness has no significant impact on Customer Satisfaction.

H1G: Refund Policy has no significant impact on Customer Satisfaction.

For the purpose of this study, Consumer characteristics has been further broken down into variables like: consumer's shopping orientation- Recreational Orientation (Consumers who enjoy shopping whether they buy or not), Experiential Orientation (Consumers who purchase the products only if they see and touch them once before its final purchase), Convenience Orientation (These consumers are busy in their routines and wish to spend least time in shopping), Economic Orientation (Consumers of this category look out for best deals whether online or offline, where they can avail maximum price benefits); Consumer's attitude towards online shopping (Determining the customer's general attitude towards shopping online) and what is their perceived risk of shopping online (What risks have they associated with online shopping). Analyzing these factors will give an estimate as to how the customer perceives the idea of shopping if given an option to purchase online or offline. This will let us understand as to which type of consumers opt for online shopping.

To analyse the customers' perception of (A) Shopping Orientations (Recreational Orientation, Experiential Orientation, Convenience Orientation and Economic Orientation) (B) Attitude towards online shopping (C) Perceived risk of shopping online on the bases of various demographic characteristics (gender, age, marital status and educational qualification), following hypotheses are formulated:

H2Aa: There is a significant difference in the perception of shopping orientations between males and females.

- H2Aa1: There is a significant difference in the perception of Recreational Orientation between males and females.

- H2Aa2: There is a significant difference in the perception of Experiential Orientation between males and females.

- H2Aa3: There is a significant difference in the perception of Convenience Orientation between males and females.

- H2Aa4: There is a significant difference in the perception of Economic Orientation between males and females.

$\mathrm{H} 2 \mathrm{Ab}$ : There is a significant difference in the perception of shopping orientations between married and unmarried population.

- H2Ab1: There is a significant difference in the perception of Recreational Orientation between married and unmarried population. 
International Journal of Management and Information Techonology

- H2Ab2: There is a significant difference in the perception of Experiential Orientation between married and unmarried population.

- H2Ab3: There is a significant difference in the perception of Convenience Orientation between married and unmarried population.

- H2Ab4: There is a significant difference in the perception of Economic Orientation between married and unmarried population.

H2Ac: There is a significant difference in the perception of shopping orientations across the age groups.

H2Ad: There is a significant difference in the perception of shopping orientations across the educational levels.

$\mathrm{H} 2 \mathrm{Ba}$ : There is a significant difference in the perception of attitude towards online shopping between males and females.

$\mathrm{H} 2 \mathrm{Bb}$ : There is a significant difference in the perception of attitude towards online shopping between married and unmarried population.

H2Bc: There is a significant difference in the perception of attitude towards online shopping across the age groups.

$\mathrm{H} 2 \mathrm{Bd}$ : There is a significant difference in the perception of attitude towards online shopping across the educational levels.

H2Ca: There is a significant difference in the perception of perceived risk of shopping online between males and females.

$\mathrm{H} 2 \mathrm{Cb}$ : There is a significant difference in the perception of perceived risk of shopping online between married and unmarried population.

$\mathrm{H} 2 \mathrm{Cc}$ : There is a significant difference in the perception of perceived risk of shopping online across the age groups.

$\mathrm{H} 2 \mathrm{Cd}$ : There is a significant difference in the perception of perceived risk of shopping online across the educational levels.

\section{ANALYSIS \& INTERPRETATIONS}

Sample Profile: This section shows the profile of 367 respondents (online travel portal users) surveyed in Delhi NCR on the basis of four variables (gender, age group, educational qualification, and marital status).

Table 1. Simple Percentage Analysis of demographic profile

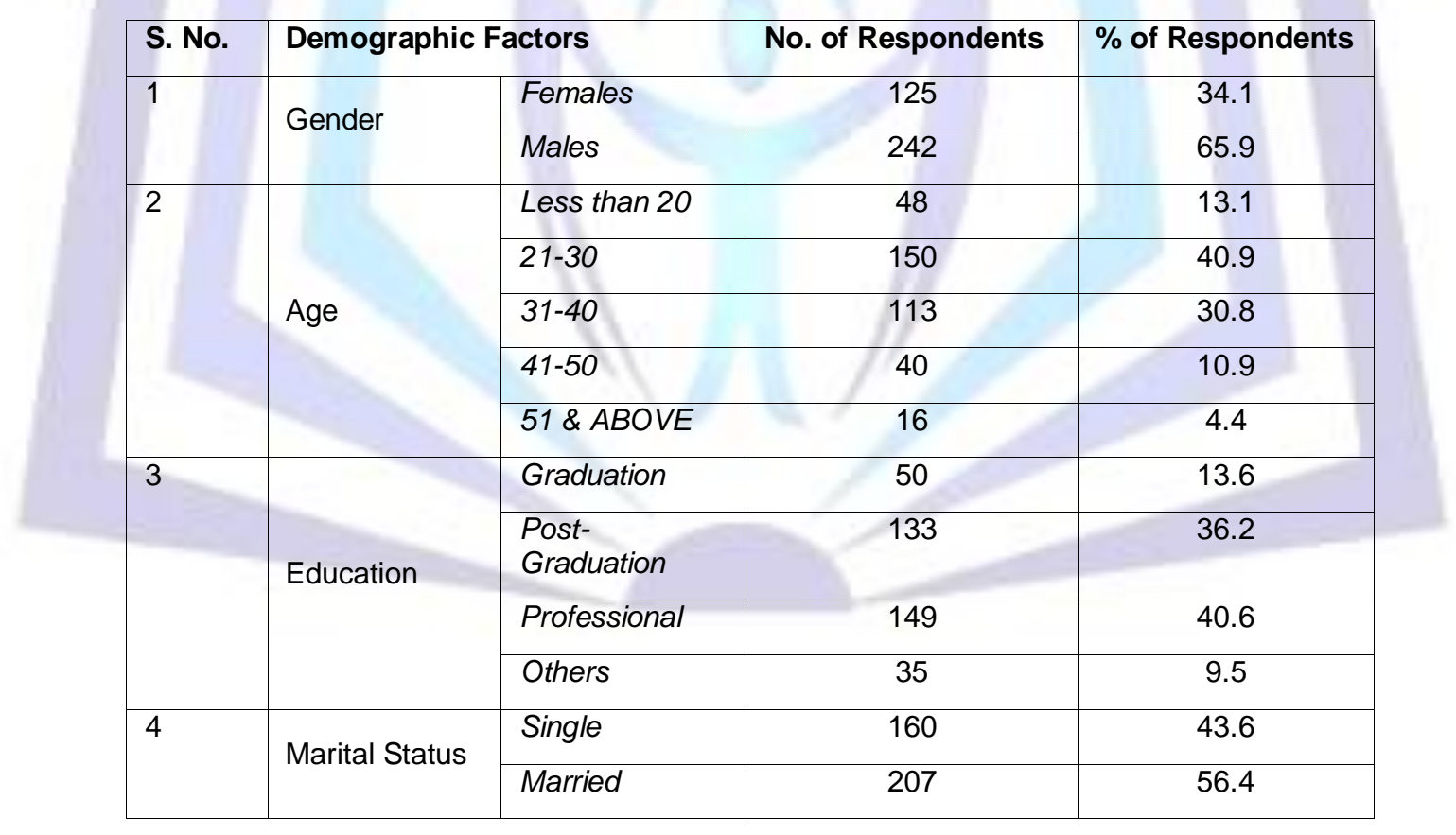

Gender: The findings in the table 1 and fig. 1 reveal that males are more inclined towards online tour planning, which is 65.9 percentage of total respondents) than females (34.1 percentage of total respondents. 


\section{Fig. 1 Sample Profile - Gender Wise}

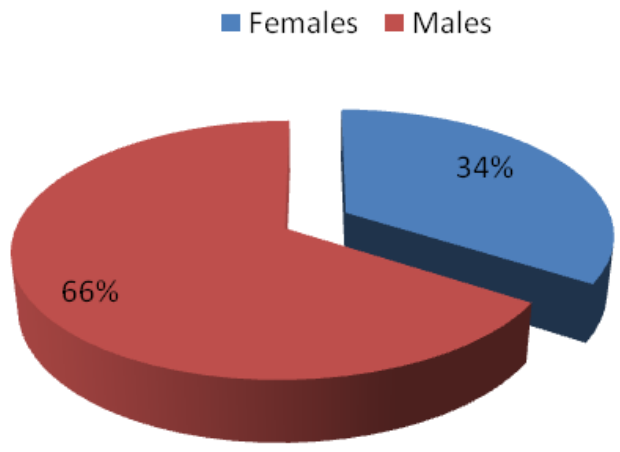

Age Group: As per the results, young generation prefers to plan tours online, as age group between 21 \& 30 years are using these services more (40.9\%) followed by those aged between $31-40$ years with a percentage of 30.8 (Fig. 2). People of age 51 years and above have showed little interest (4.4\%) in planning tours online.

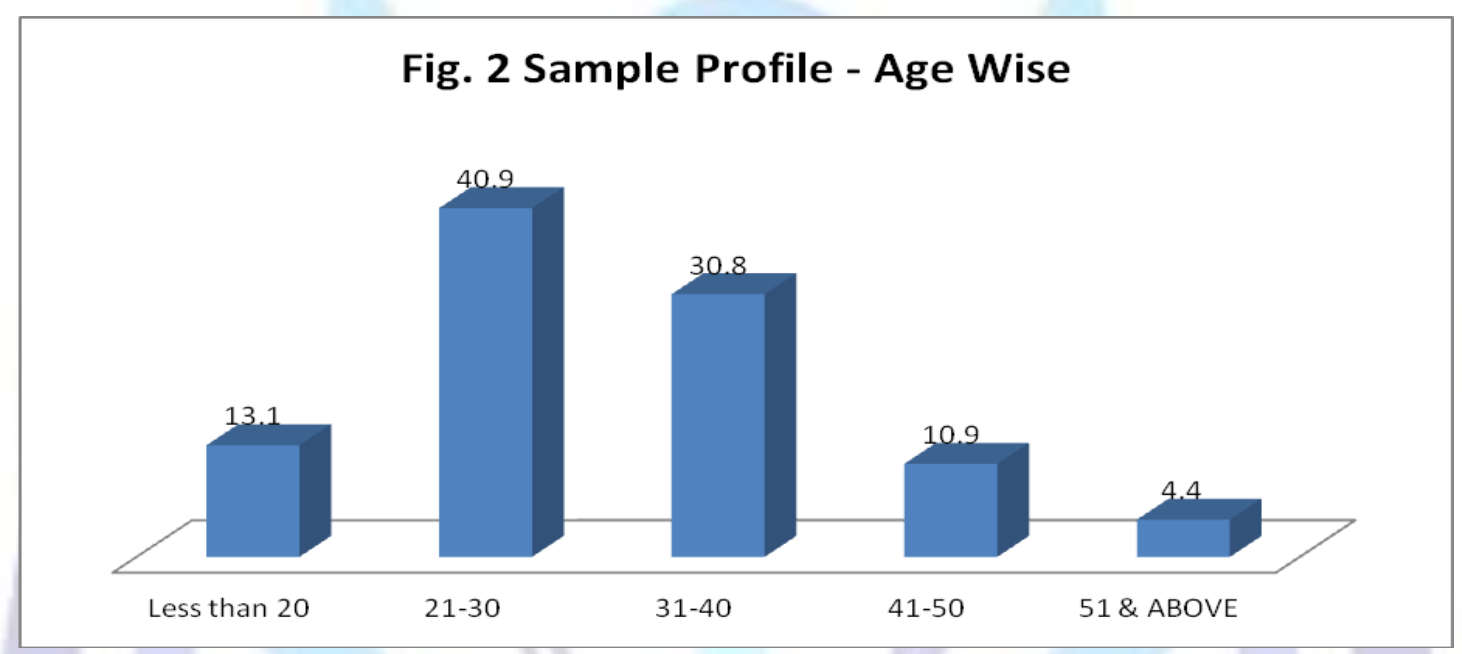

Educational Qualification: As high as $40.6 \%$ of the respondents possess professional qualification, whereas $36.2 \%$ of respondents are post-graduates indicating that most of the population are highly educated who are using online services to plan tours than those with lower education levels (Fig.3).

\section{Fig. 3 Sample Profile - Educational Qualification Wise}

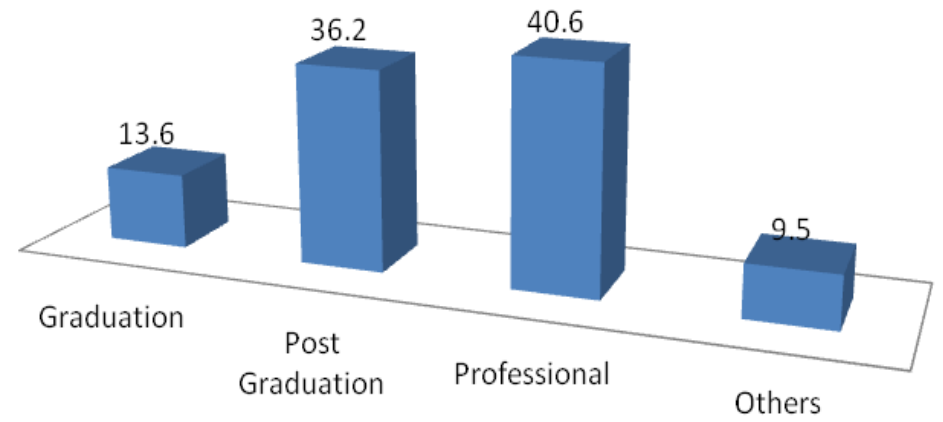

Marital Status: Not much of a difference can be seen amongst the respondents in terms of their marital status, signifying that online tour planning is famous amongst the ones who are married as well as unmarried (Fig. 4). 


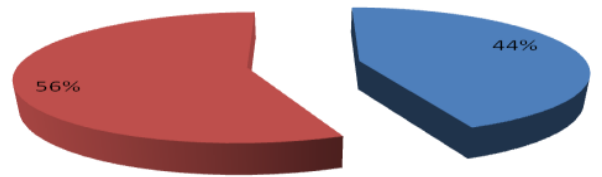

\section{Impact of Consumer Trust on Customer Satisfaction}

This study is an extension of the researcher's previous study of identifying antecedents of consumer trust for e-tourism companies in India. The study concluded with the identification of seven factors, namely: website characteristics, personalization, website information, promotional deals, availability, price competitiveness and refund policy; that build trust in online tourism companies in India. This study tries to explore the relationship between factors that build trust of the consumers on the online companies and their satisfaction level. Multiple Regression technique has been used to test the hypothesis $\mathrm{H} 1 \mathrm{~A}-\mathrm{H} 1 \mathrm{G}$. Table 2 shows the result obtained by regressing website characteristics, Personalization, website information, promotional deals, availability, price competitiveness and refund policy on Customer satisfaction.

Table 2: Regression Results for Consumer Trust Dimensions on Customer Satisfaction

\begin{tabular}{|c|c|c|c|}
\hline & Standardized Beta ( $\square$ & t & Sig. \\
\hline Website Characteristics & .046 & .750 & .454 \\
\hline Personalization & .034 & .562 & .574 \\
\hline Website Information & -.038 & -.618 & .537 \\
\hline Promotional Deals & .124 & 2.393 & $.017^{\star *}$ \\
\hline Availability & -.024 & -.395 & .693 \\
\hline Price competitiveness & .137 & 2.627 & $.009^{\star}$ \\
\hline Refund Policy & .075 & 1.448 & .48 \\
\hline
\end{tabular}

Dependent Variable: Customer Satisfaction

$F=2.166$ (sig. at $p<.05$ ), $R=.201, R^{2}=.041$, adj $R^{2}=.022$

$$
{ }^{*} \mathrm{p}<.01,{ }^{* *} \mathrm{p}<.05
$$

Table 2 indicates that amongst seven Consumer Trust dimensions, only "Promotional deals" and "Price Competitiveness" have a significant positive impact on "Consumer Trust", whereas the impact of other five variables are not significant. Therefore, hypotheses $\mathrm{H} 1 \mathrm{D}$ and $\mathrm{H} 1 \mathrm{~F}$ are rejected whereas hypotheses $\mathrm{H} 1 \mathrm{~A}, \mathrm{H} 1 \mathrm{~B}, \mathrm{H} 1 \mathrm{C}, \mathrm{H} 1 \mathrm{E}$ and $\mathrm{H} 1 \mathrm{G}$ are accepted. Moreover, "Promotional Deals" has lesser impact $(\square=.124, p<.05)$ than that of "Price Competitiveness" $(\square=.137, p<.01)$ on Consumer Trust.

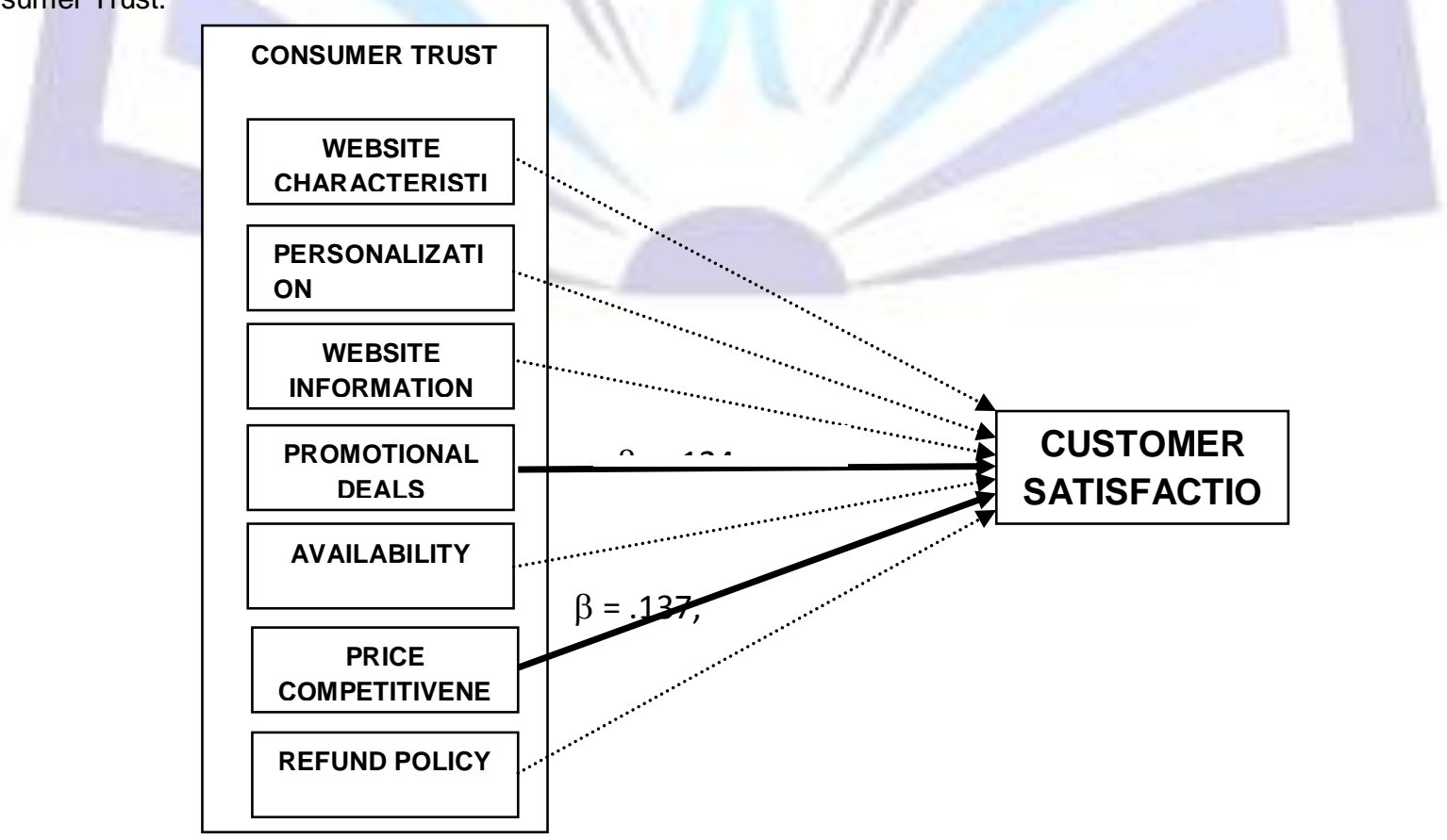


Fig. 5 Impact of Consumer Trust on Customer Satisfaction

The impact of all seven factors of consumer trust on customer satisfaction has been studied. Out of all the seven factors, only Promotional Deals and Price Competitiveness significantly influence Customer Satisfaction (see fig. 5). The analytical result is consistent with previous findings of researchers. Goswami et al, 2013 concluded with similar results stating that price factor should be given importance in order to create satisfied customers as well as the marketers should also offer new schemes to attract the new customers. Also, the theory is further supported by Bhandari \& Kaushal (2013) who identified Bargain Shopping as one of the six factors crucial for online shopping.

\section{Impact of Demographics on Consumer Characteristics.}

Mean Scores-Demography Wise: Tables 3 shows the mean scores by demographic variables (gender, marital status, age group and educational qualification) for various shopping orientations (Recreational Orientation, Experiential Orientation, Convenience Orientation and economic Orientation).

Table 3 Mean Scores for Shopping Orientations of Respondents - Demography Wise

\begin{tabular}{|c|c|c|c|c|c|c|c|}
\hline \multicolumn{2}{|c|}{ DEMOGRAPHIC VARIABLES } & \multirow{2}{*}{$\begin{array}{l}\text { RO } \\
2.38\end{array}$} & \multirow{2}{*}{$\begin{array}{l}\text { EO } \\
2.64 \\
\end{array}$} & \multirow{2}{*}{$\begin{array}{c}\text { Co } \\
3.95\end{array}$} & \multirow{2}{*}{$\begin{array}{l}\text { ECO } \\
4.12\end{array}$} & \multirow{2}{*}{$\begin{array}{l}\text { ATOS } \\
3.76\end{array}$} & \multirow{2}{*}{$\begin{array}{l}\text { PRSO } \\
2.34 \\
\end{array}$} \\
\hline Gender & Males & & & & & & \\
\hline & Females & 2.81 & 3.11 & 3.49 & 4.13 & 3.28 & 2.84 \\
\hline \multirow[t]{2}{*}{ Marital Status } & Single & 2.76 & 3.04 & 3.65 & 4.12 & 3.36 & 2.77 \\
\hline & Married & 2.34 & 2.62 & 3.91 & 4.13 & 3.78 & 2.31 \\
\hline \multirow[t]{5}{*}{ Age } & $>20$ & 1 & 1 & 5.00 & 3.89 & 5 & 1 \\
\hline & $21-30$ & 1.72 & 2.09 & 4.64 & 4.36 & 4.51 & 1.47 \\
\hline & $31-40$ & 3.27 & 3.54 & 3.01 & 4.00 & 2.86 & 3.39 \\
\hline & $41-50$ & 4.26 & 4.66 & 1.98 & 4.03 & 1.63 & 4.77 \\
\hline & $<50$ & 5 & 5 & 2.33 & 3.66 & 1 & 5 \\
\hline \multirow{4}{*}{$\begin{array}{l}\text { Educational } \\
\text { Qualification }\end{array}$} & Graduation & 3.23 & 3.36 & 3.55 & 4.05 & 3.09 & 3.05 \\
\hline & Post Grad. & 2.55 & 2.86 & 3.70 & 4.20 & 3.57 & 2.56 \\
\hline & Professional & 2.37 & 2.68 & 3.87 & 4.11 & 3.69 & 2.40 \\
\hline & Others & 2.08 & 2.32 & 4.18 & 4.00 & 4.02 & 2.04 \\
\hline
\end{tabular}

Table 3 indicates the mean scores of shopping orientations of the respondents. It can be revealed from the table that males have more of economic orientation, whereby they want more value for money and at the same time, while not compromising on convenience in shopping. The comparative mean score indicates that females have a higher tendency towards Experiential shopping than males. Respondents who were single also enjoy shopping more than the married respondents.

Overall Mean Scores: Table 4 shows the mean scores for all the items of "Shopping Orientations". It can be noticed that "Economic Orientation" followed by "Convenience Orientation" have received the highest mean ratings of 4.13 and 3.79 respectively whereas, "Experiential Orientation" and "Recreational orientation" have received lower scores of 2.81 and 2.53. This indicates that respondents do not prefer to shop around by looking at displays but they seek convenience in shopping while not compromising the economical aspect of the same. Hence, they resort to online shopping.

\begin{tabular}{|l|l|l|l|}
\hline \multirow{4}{*}{$\begin{array}{c}\text { Recreational } \\
\text { Orientation } \\
\text { (Mean }=2.53)\end{array}$} & RO1 & Window shopping is usually a pleasant experience for me. & 2.51 \\
\cline { 2 - 5 } & RO2 & I like to shop around and look at displays. & 2.51 \\
\cline { 2 - 5 } & RO3 & I never feel bored when I go shopping. & 2.56 \\
\hline $\begin{array}{l}\text { Experiential } \\
\text { Orientation } \\
\text { (Mean }=2.81)\end{array}$ & EO1 & I like to see and touch products before I buy them. & 2.90 \\
\cline { 2 - 5 } & EO2 & I hate buying things without seeing what I am getting. & 2.91 \\
\cline { 2 - 5 } & EO3 & I like to try it before I buy a product. & 2.61 \\
\hline
\end{tabular}


International Journal of Management and Information Techonology

\begin{tabular}{|l|l|l|l|}
\hline $\begin{array}{l}\text { Convenience } \\
\text { Orientation } \\
\text { (Mean = 3.79) }\end{array}$ & CO1 & I hate to wait in long lines for checking out goods. & 3.61 \\
\cline { 2 - 5 } & CO2 & Saving time while shopping is very important to me. & 3.66 \\
\cline { 2 - 5 } & CO3 & I want to be able to shop at any time of the day. & 4.11 \\
\hline $\begin{array}{l}\text { Economic } \\
\text { Orientation } \\
(\text { Mean = 4.13) }\end{array}$ & ECO1 & Being a smart shopper is worth the extra time it takes. & 4.19 \\
\cline { 2 - 5 } & ECO2 & I like to shop around for the best buy and feel great with a good deal. & 4.14 \\
\cline { 2 - 5 } & ECO3 & I like to consider a wide selection before making a purchase. & 4.05 \\
\hline
\end{tabular}

Table 4 Item-Wise Mean Score of Shopping Orientations of Respondents

Table 5 shows the mean scores for the Customer's perception about Online Shopping. The table indicates that the customers enjoy online shopping as attitude towards online shopping has a mean score of 3.60 and find it to be less risky which is justified with a low mean score of 2.51 .

\section{Table 5 Item-Wise Mean Score of Customer's Perception about Online Shopping}

\begin{tabular}{|l|l|l|l|}
\hline \begin{tabular}{l} 
Attitude towards $\begin{array}{c}\text { online shopping } \\
\text { (Mean }=3.60)\end{array}$ \\
\cline { 2 - 4 }
\end{tabular} & ATOS1 & I enjoy shopping online & 3.66 \\
\cline { 2 - 4 } & ATOS3 & Shopping on internet is easy. & 3.77 \\
\hline $\begin{array}{l}\text { Perceived risk of } \\
\text { shopping online } \\
\text { (Mean = 2.51 })\end{array}$ & PRSO1 & Shopping on Internet is risky & 3.37 \\
\cline { 2 - 4 } & PRSO2 & There is too much uncertainty associated with online shopping. & 2.46 \\
\cline { 2 - 4 } & PRSO3 & In comparison to other modes, shopping online is riskier. & 2.42 \\
\hline
\end{tabular}

Table 5 reveals that the websites of the online tourism companies are attractive with an impressive layout and design, providing easy navigation, etc. (mean score for website characteristics $=3.536$ ). But, at the same time the websites are not providing up-to-date information, personalized services and effective refund policies (mean scores $<3$ ). Further, the customers are attracted towards online tourism because of promotional offers and schemes, easy availability and price competitiveness.

The hypotheses $\mathrm{H} 2 \mathrm{Aa}, \mathrm{H} 2 \mathrm{Ab}, \mathrm{H} 2 \mathrm{Ba}, \mathrm{H} 2 \mathrm{Bb}, \mathrm{H} 2 \mathrm{Ca}$ and $\mathrm{H} 2 \mathrm{Cb}$ have been tested by using Independent Samples t-test whereas MANOVA test has been used to test the hypotheses $\mathrm{H} 2 \mathrm{Ac}, \mathrm{H} 2 \mathrm{Ad}, \mathrm{H} 2 \mathrm{Bc}, \mathrm{H} 2 \mathrm{Bd}, \mathrm{H} 2 \mathrm{Cc}$ and $\mathrm{H} 2 \mathrm{Cd}$.

The results obtained through independent samples t-test on customer perceptions about online shopping in general between categories related to gender i.e., males and females are presented in table 6 . Results of Levene's Test for Equality of Variances reveal that variances among perceptions of married and unmarried people are equal only for Experiential orientation $(F=2.086, p>.01)$. Therefore, for this dimension, $t$-values in the 'equal variance assumed' row will be used for analysing the results of independent samples t-test, whereas t-value in the 'equal variance not assumed' row will be used for analysing the remaining shopping orientations (recreational, economical and convenience), attitude towards online shopping and perceived risk of shopping online $(p<.01)$. Further, it is found that except for economic orientation ( $\mathrm{t}=301.065, \mathrm{p}>.01)$, significant differences in the perceptions of all other consumer characteristics are observed between males and females. Therefore, $\mathrm{H} 2 \mathrm{Aa} 4$ is rejected whereas $\mathrm{H} 2 \mathrm{Aa} 1, \mathrm{H} 2 \mathrm{Aa} 2, \mathrm{H} 2 \mathrm{Aa} 3, \mathrm{H} 2 \mathrm{Ba}$ and $\mathrm{H} 2 \mathrm{Ca}$ are accepted. Further, it can be noticed from Table 3 that females consider shopping as more of recreational and experiential experience (Mean Scores $=2.81 \& 3.11$ respectively) than males. Whereas, males are more convenience oriented (mean Score $=3.95$ ).

Table 6: Results of Independent Sample t-test for Shopping Orientation and Perception about online shopping between Males and Females

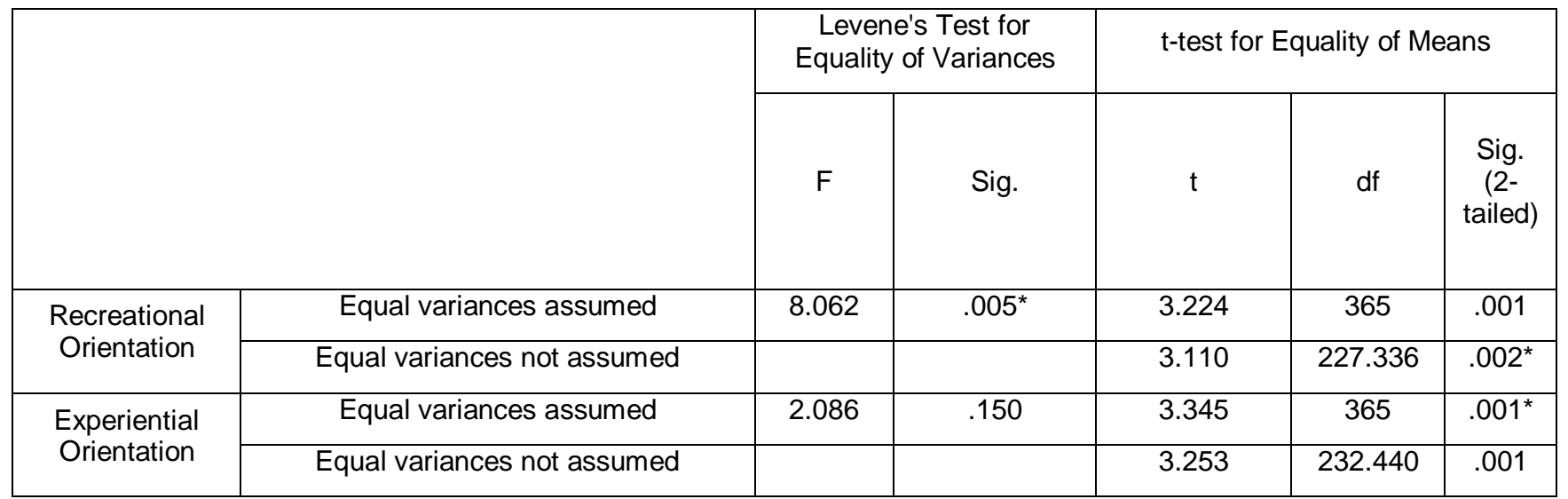

2680 | P a g e

council for Innovative Research 
Tnternational Journal of Management and Information Techonology

\begin{tabular}{|c|c|c|c|c|c|c|}
\hline $\begin{array}{c}\text { Convenience } \\
\text { Orientation }\end{array}$ & Equal variances assumed & 27.257 & $.000^{*}$ & -3.764 & 365 & .000 \\
\cline { 2 - 7 } & Equal variances not assumed & & & -3.514 & 208.749 & $.001^{*}$ \\
\hline $\begin{array}{c}\text { Economic } \\
\text { Orientation }\end{array}$ & Equal variances assumed & 9.315 & $.002^{*}$ & .305 & 365 & .761 \\
\cline { 2 - 7 } & Equal variances not assumed & & & .326 & 301.065 & .745 \\
\hline $\begin{array}{c}\text { Attitude } \\
\text { towards online } \\
\text { shopping }\end{array}$ & Equal variances assumed & 13.727 & $.000^{*}$ & -3.411 & 365 & .001 \\
\cline { 2 - 7 } & Equal variances not assumed & & & -3.246 & 219.488 & $.001^{*}$ \\
\hline $\begin{array}{c}\text { Perceived Risk } \\
\text { of shopping } \\
\text { online }\end{array}$ & Equal variances assumed & 13.985 & $.000^{*}$ & 3.256 & 365 & .001 \\
\cline { 2 - 7 } & Equal variances not assumed & & & 3.105 & 220.471 & $.002^{*}$ \\
\hline
\end{tabular}

The results obtained through independent samples t-test on customer perceptions about online shopping in general between categories related to marital status i.e. married and unmarried population are presented in table 7 . It can be seen that except for economic orientation ( $\mathrm{t}=306.501, \mathrm{p}>$.01), significant differences in the perceptions of all other consumer characteristics are observed between married and unmarried population. Therefore, H2Ab4 is rejected whereas H2Ab1, $\mathrm{H} 2 \mathrm{Ab} 2, \mathrm{H} 2 \mathrm{Ab} 3, \mathrm{H} 2 \mathrm{Bb}$ and $\mathrm{H} 2 \mathrm{Cb}$ are accepted. Further, it can be inference from the table 3 that unmarried respondents are more inclined towards Recreational Orientation (Mean Score $=2.76$ ) and Experiential Orientation (Mean Score = 3.04). On the other hand, Married respondents are more focused on convenience orientation (Mean Score $=3.91$ )

Table 7 Results of Independent Sample t-test for Shopping Orientation and Perception about online shopping between Married \& Unmarried Population

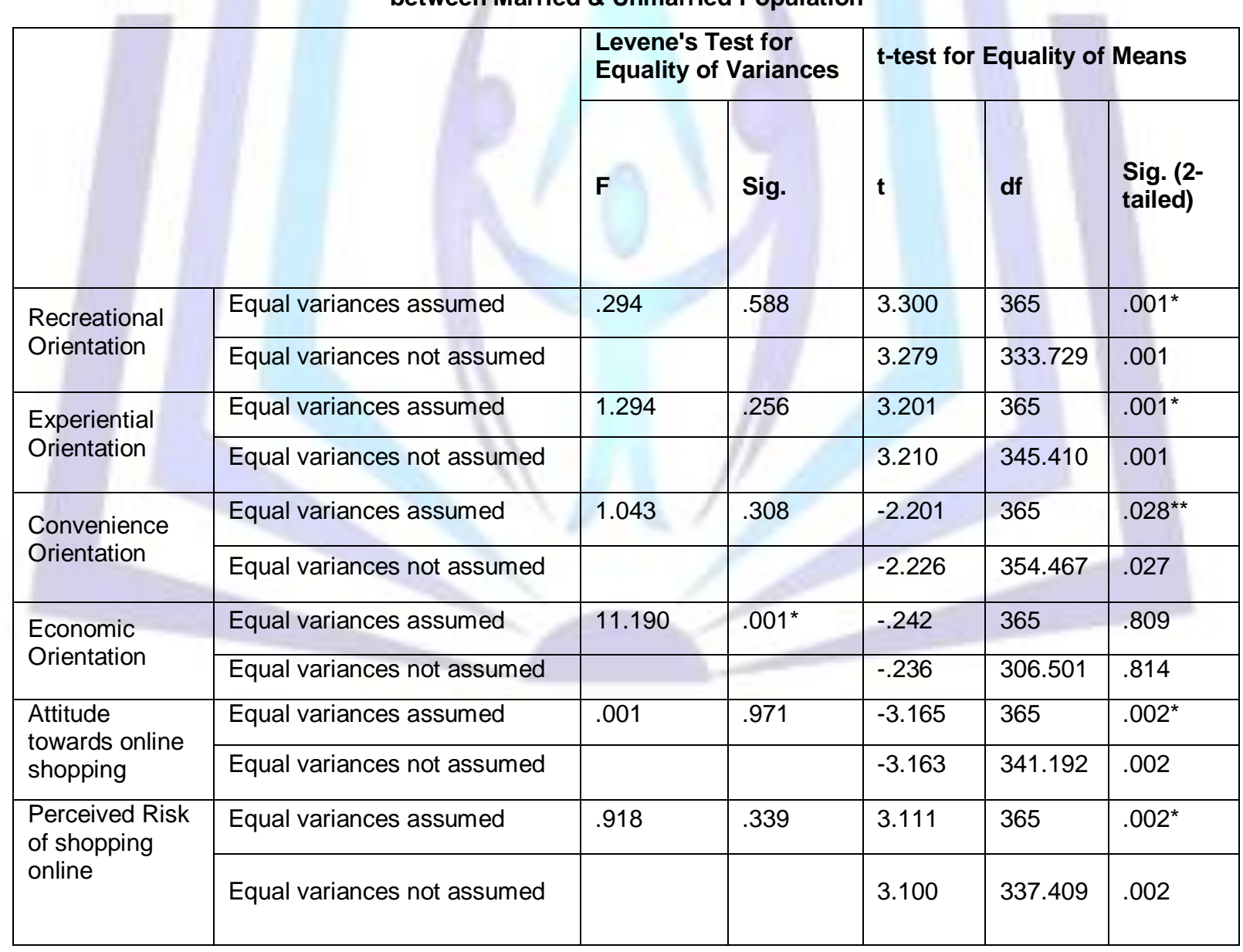

The summary of MANOVA results for demographic variables (age group and educational qualification) is reported in tables 8 and 9 . Results in table 8 indicate that there are significant differences in the customers' perception of shopping orientation and online shopping on the bases of age group (Wilks' Lambda=.870, $F=2.035, p<.01$ ), and educational qualification (Wilks' Lambda=.792, F=3.456, p<.01). Therefore, H2Ac and H2Ad are accepted. 

International Journal of Management and Information Techonology Table 8 MANOVA Summary for Demographic Variables

\begin{tabular}{|c|c|c|c|c|}
\hline \multicolumn{2}{|c|}{ Effect } & Value & F & Sig. \\
\hline Age Group & Wilks' Lambda & .900 & 2.314 & .002 \\
\hline Educational Qualification & Wilks' Lambda & .823 & 4.349 & .000 \\
\hline
\end{tabular}

Further, Table 9 indicates that on the basis of age group, there are significant differences in the perceptions of Recreational Orientation \& Experiential Orientation $(p<.05)$. Whereas, on the basis of educational qualification, it can be inference that, there are significant differences in the perceptions of Recreational Orientation \& Convenience Orientation $(p<.10)$.

Table 9 Follow-up Test-Univariate ANOVA for Age Group and Educational Qualification

\begin{tabular}{|c|c|c|c|c|c|c|}
\hline Source & $\begin{array}{c}\text { Dependent } \\
\text { Variable }\end{array}$ & $\begin{array}{l}\text { Type III Sum of } \\
\text { Squares }\end{array}$ & df & Mean Square & $\mathbf{F}$ & Sig. \\
\hline \multirow{4}{*}{ Age Group } & $\mathrm{RO}$ & 15.891 & 4 & 3.973 & 3.091 & $.016^{\star *}$ \\
\hline & EO & 16.644 & 4 & 4.161 & 2.953 & $.020^{* *}$ \\
\hline & $\mathrm{CO}$ & 7.490 & 4 & 1.873 & 1.599 & .174 \\
\hline & ECO & .561 & 4 & .140 & 1.169 & .324 \\
\hline \multirow{4}{*}{$\begin{array}{l}\text { Educational } \\
\text { Qualification }\end{array}$} & $\mathrm{RO}$ & 11.415 & 4 & 2.854 & 2.220 & $.066^{\star \star *}$ \\
\hline & EO & 10.186 & 4 & 2.546 & 1.807 & .127 \\
\hline & $\mathrm{CO}$ & 10.884 & 4 & 2.721 & 2.323 & $.056^{* * *}$ \\
\hline & ECO & .855 & 4 & .214 & 1.782 & .132 \\
\hline
\end{tabular}

Tables 10 \& 11 show the results of One-way ANOVA for testing difference in the perceptions of Attitude towards online shopping on the basis of age group and educational qualifications respectively. While Tables $12 \& 13$ show the results of One-way ANOVA for testing difference in the perceptions of Perceived risk for shopping online on the basis of age group and educational qualifications respectively. Results reveal that the perceptions of ATOS differ significantly on the basis of age group $(F=5.714, p<.01)$ and educational qualification $(F=3.192, p<.05)$. Also, there are significant differences in the perceptions of PRSO on the basis of age group $(F=4.958, p<.01)$ and educational qualification $(F=3.177, p<.05)$. Therefore, H2Bc, H2Bd, H2Cc \& H2Cd are accepted. Elderly people are inclined more towards RO \& EO (Mean score = 5) whereas younger people are more towards CO \& ECO (Mean Score $=5,4.36$ respectively).

Table 10 ANOVA on Attitude towards Online Shopping for Age Group

\begin{tabular}{|c|c|c|c|c|c|}
\hline & Sum of Squares & df & Mean Square & F & Sig. \\
\hline Between Groups & 36.128 & 4 & 9.032 & 5.714 & .000 \\
\hline Within Groups & 572.201 & 362 & 1.581 & & \\
\hline Total & 608.329 & 366 & & & \\
\hline
\end{tabular}

Table 11 ANOVA on Attitude towards Online Shopping for Educational Qualification

\begin{tabular}{|l|l|l|l|l|l|}
\hline & Sum of Squares & df & Mean Square & F & Sig. \\
\hline Between Groups & 20.728 & 4 & 5.182 & 3.192 & .013 \\
\hline Within Groups & 587.602 & 362 & 1.623 & & \\
\hline Total & 608.329 & 366 & & & \\
\hline
\end{tabular}


Table 12 ANOVA on Perceived Risk of Shopping Online for Age Group

\begin{tabular}{|c|c|c|c|c|c|}
\hline & Sum of Squares & $\mathrm{df}$ & Mean Square & $\mathrm{F}$ & Sig. \\
\hline Between Groups & 38.479 & 4 & 9.620 & 4.958 & .001 \\
\hline Within Groups & 702.319 & 362 & 1.940 & & \\
\hline Total & 740.797 & 366 & & & \\
\hline
\end{tabular}

Table 13 ANOVA on Perceived Risk of Shopping Online for Educational Qualification

\begin{tabular}{|c|c|c|c|c|c|}
\hline & Sum of Squares & $\mathrm{df}$ & Mean Square & $\mathrm{F}$ & Sig. \\
\hline Between Groups & 25.120 & 4 & 6.280 & 3.177 & .014 \\
\hline Within Groups & 715.677 & 362 & 1.977 & & \\
\hline Total & 740.797 & 366 & & & \\
\hline
\end{tabular}

\section{Findings of the study}

\section{Impact of Consumer Trust on Customer Satisfaction}

The impact of all seven factors of consumer trust on customer satisfaction has been studied. Out of all the seven factors, only Promotional Deals and Price Competitiveness significantly influence Customer Satisfaction (see fig. 5).

Indian Customers are more attracted by promotional deals and discount offers which are available more on the tourism websites (than with the travel agents) because of which they feel more satisfied with online tour planning.

Similarly, provision of competitive prices of travel mode; accommodation, etc. also lead to more satisfaction of customers.

Although the customers find the tourism websites efficient and easy to navigate and are also impressed by the layout, graphics and all time availability of the website, but this doesn't lead to their satisfaction. This may be due to the fact that these are evaluated as "Expected Quality" parameters, which should be present in a website.

Despite the fact that online tourism companies lack to cater the specific needs of the customers, lack in providing efficient refund policies and updated information, still the customers are attracted towards tourism websites because of their promotional offers and price competitiveness. They don't expect personalized attention and feel satisfied only if they get attractive discount offers and schemes.

\section{Impact of Demographic Characteristics on Consumer Characteristics}

In the present study, three consumer characteristics i.e. Shopping orientations (which is further subdivided into four parts; Recreation, Experiential, Convenience and Economic Orientation), Attitude towards online shopping and Perceived risk of shopping online have been identified on the basis of literature review. The impact of four demographic variables i.e. gender, marital status, educational qualification and age have been studied on all the three consumer characteristics. Significant differences are found in the perceptions of consumer characteristics on the basis of all demographic variables except for educational qualifications. The detailed findings are as given below:

It has been found that except for Economic Orientation, perceptions of all other consumer characteristics differ significantly for males and females. Females are found to have more recreational orientation, experiential orientation and perceived risk of shopping online whereas males are found to have more inclination towards convenience orientation and attitude towards online shopping.

Higher recreational orientation of females can be explained by considering the fact that they never get bored while shopping by looking at displays, whereas males don't consider it as a very pleasant experience.

Higher experiential orientation of females is justifiable because they prefer to see and touch the products before buying them and also try the same before finally buying it, whereas their male counterparts lack these attributes.

Since females are risk-avoiders, their perceived risk of shopping online is higher than that of males. Females consider online shopping to be more uncertain and risky in nature as compared to other modes of shopping. 

Anytime and anywhere shopping grab the attention of males towards online shopping because of which their convenience orientation is higher than those of females. Also, they hate to wait in long lines and want to save time while shopping.

Males' attitude towards online shopping is more positive than females as they enjoy online shopping as they find it easy and convenient.

Except for Economic Orientation, the perceptions of married and unmarried respondents are found to be significantly different for all the other consumer characteristics. Unmarried respondents are found to have more recreational orientation, experiential orientation and perceived risk of shopping online whereas married respondents are found to have more inclination towards convenience orientation and attitude towards online shopping.

Higher recreational orientation of unmarried respondents can be explained by considering the fact that they like to shop around and also go for window shopping, whereas married respondents don't consider shopping to be a very pleasant experience.

Higher experiential orientation of unmarried respondents is justifiable because they hate buying things without seeing what they are buying and like trying them before final purchase, whereas the married respondents have lesser interest in the same.

Perceived risk of shopping online is higher in case of unmarried respondents than married respondents. This is so because they perceive it riskier as compared to other modes of shopping.

Convenience orientation is higher in case of married respondents than those of unmarried respondents as they want to shop at any time of the day in order to save their time, which is not given much preference by unmarried respondents.

Attitude towards online shopping is more positive in case of married respondents than the unmarried ones as they find online shopping to be easier, convenient and hassle free.

Results reveal that perceptions of respondents lying in different age brackets are different for Recreational Orientation, Experiential Orientation, Attitude towards online shopping and Perceived risk of shopping online, but they don't exhibit differences in in perceptions of Convenience orientation and economic orientation. Recreational orientation and experiential orientation show an increasing trend with the age of the customers.

Since, the elderly customers have been always exposed to shopping via looking at displays; they enjoy this form of shopping more than any other mode. Rather, they consider it to be a pleasant experience which is not given much of weightage by younger generation as they are exposed to new forms of shopping.

Elderly people prefer to see and touch the things before buying them and they actually hate to buy things without seeing them. This justifies their experiential orientation, which is not in the case of younger generation.

\section{Conclusion}

From the above findings, it can be concluded that, Indian Customers are more attracted by promotional deals and discount offers which are available more on the tourism websites (than with the travel agents) because of which they feel more satisfied with online tour planning. Similarly, provision of competitive prices of travel mode, accommodation, etc. also lead to more satisfaction of customers. This may be due to the fact that these are evaluated as "Expected Quality" parameters, which should be present in a website. Like any other research; demographics play a major role in the usage of internet as a mode of shopping. Companies can use this information and actually target its consumers effectively and efficiently. Their perceptions regarding online shopping and associated risks can be helpful for the companies in designing better marketing strategies. This study can be further explored to frame customer attraction and retention strategies.

\section{References}

[1] Alba, J., Lynch, J., Weitz, B., Janiszewski, C., Lutz, R., Saywer, A., \& Wood, S. (1997). Interactive home shopping: Consumer, retailer and manufacturer incentives to participate in electronic marketplace. Journal of Marketing, 61(July), 3853.

[2] Bajs, I. (2011). Attributes of Tourist destination as Determinants of Tourist Perceived Value. International Journal of Management Cases 13(3): 547-554.

[3] Bauernfeind, U. and Zins, A.H. (2006). The Perception of Exploratory browsing and Trust with Recommender websites. Journal of Information Technology \& Tourism. 8(2): 121-136.

[4] Brown, M. R., Muchira, R. and Gottlieb, U. (2007). Privacy Concerns and the Purchasing of Travel Services Online. Journal of Information Technology \& Tourism. 9(1): 15-25.

[5] Chang, H. H., Wang, Y., \& Yang, W. (2009). The impact of e-service quality, customer satisfaction and loyalty on emarketing: Moderating effect of perceived value. Total Quality Management. 20(4), 423-443.

[6] Chen, C. (2006). Identifying Significant factors influencing consumer trust in an online travel site. Journal of Information Technology and Tourism 8(34): 197-214.

[7] Fishbein, M. and Ajzen, I. (1975). Belief, attitude, intention \& behaviour: An introduction to theory \& research. Reading, MA: Addison-Wesley.

$\mathbf{2 6 8 4} \mid \mathrm{P}$ a g e 
International Journal of Management and Information Techonology [8] Flavian, C., Guinaliu, M. and Gurrea, R. (2006). The role played by perceived usability, satisfaction and consumer trust on website loyalty. Information \& Management. 43(1): 1-14.

[9] Furse, D. H., Punj, G. N. \& Stewart, D. W. (Eds.). (1982). Individual serach strategies in new automobile purchases. Ann Arbor: Association for consumer Research.

[10] Greenfield Online. (1999). Shopping 2000: A digital consumer study (April 1999), [www]. Available: http://www.greenfieldcentral.com/research findings/Shopping\%202000/shopping 2000.htm [1999, May 28].

[11] Hallem, Y. and Barth, I. (2011). Customer-Perceived Value of Medical Tourism: An Exploratory Study - The case of Cosmetic surgery in Tunisia. Journal of Hospitality and Tourism Management 18(1): 121-129.

[12] Heskett, J. and Jones, T. (2008). Putting the Service-Profit Chain to work. Harvard Business Review 86(7/8): 118-129.

[13] Huh, J. and Shin, W. (2009). Consumer trust in Direct-to-Consumer RX Drug Websites and its influence on Consumers' responses to the websites. American Academy of Advertising Conference proceedings. 26.

[14] Korgaonkar, P. K. (1981). Shopping orientations, importance of store attributes, demographics and store patronage: $A$ multivariate investigation. Akron Business and economic Review, 12(4), 34-38.

[15] Kim, H., Park, K. and Schwarz, N. (2010). Will this Trip really be Exciting? The role of Incidental Emotions in Product Evaluation. Journal of Consumer Research 36(6): 983-991.

[16] Lertwarinawit, A. and Gulid, N. (2011). International Tourists' Service Quality Perception and Behavioral Loyalty toward Medical Tourism in Bangkok Metropolitian Area. Journal of Applied Business Research 27(6): 1-11.

[17] Li, H., Kuo, C. \& Rusell, M. G. (1999). The impact of perceived channel utilities, shopping orientations and demographics on the consumer's online buying behaviour. Journal of Computer - Mediated Communication, 5: 0. Doi: 10.1111/j.1083-6101.19999.tb00336.x

[18] Lumpkin, J. R. (1985). Marketplace needs of the elderly: Determinant attitudes and store choice. Journal of Retailing. 61(2), 75-106.

[19] Nysveen, H., Methlie, L. and Pedersen, P. (2003). Tourism websites and value-added services: The gap between customer preferences and websites' offerings. Journal of Information Technology and Tourism 5(3): 165-174.

[20] Phelan, K., Christodoulidou, N., Countryman, C. C. and Kistner, L. J. (2011). To Book or not to Book: the role of hotel web site heuristics. Journal of Services Marketing 25(2): 134-148.

[21] Phutela, N. and Dasgupta, H. (2014). Study on factors influencing consumer trust for e-tourism companies in India. Journal of Research in Commerce and Management. 3(9): 24-34.

[22] Rust, R. T. \& Oliver, R. L. (1994). Service Quality: Insights and managerial implications from the frontier. In R. T. Rust \& R. L. Oliver (Eds.), Service Quality: New directions in theory and practice (pp. 1-20). Thousand Oaks, CA: Sage Publications.

[23] Sahadev, S. and Islam, N. (2005). Exploring the Determinants of E-Commerce Usage in the Hotel industry in Thailand: An Empirical study. Journal of Information Technology and Tourism. 7(3-4): 171-180.

[24] Shim, S., Mary Ann, E., Lotz, S. L. and Warrington, P. (2001). An online pre-purchase intentions model: The role of intention to search. Journal of Retailing 77: 397-416.

[25] Stone, G. P. (1954). City and urban identification: Observations on the social psychology of social life, 60 (July), 3645.

[26] Walsh, M., Lynch, P. and Harrington, D. (2011). A Capability-Based Framework for Tourism Innovativeness. Irish Journal of Management 31(1): 21-41.

[27] Wen, I. (2010). Online Travelers' decision Makings: A new Equation Model to evaluate impacts of website, search intention and Trust. Journal of Information Technology \& Tourism. 10(2): 153-173. 


\section{International Journal of Management and Information Techonology}

\section{Author' biography with Photo}

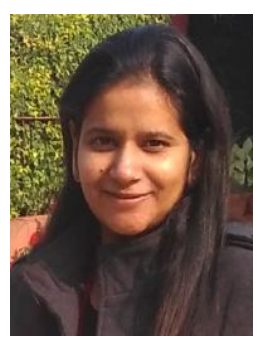

Ms Nidhi Phutela is a research scholar in Management of Lovely Professional University. She has submitted her thesis in December 2014. She is UGC-NET Qualified, M-Phil (business management) \& MBA rank holder with more than $11 \mathrm{yrs}$ of experience in teaching MBA and CA students. She has worked on the editorial board of 2 journals. She has to her credit 6 publications in peer reviewed national \& international journals, has authored one book and has presented 4 papers in International conferences. Her research interest areas include: Consumer behaviour, Customer Relationship Management \& Tourism Industry.

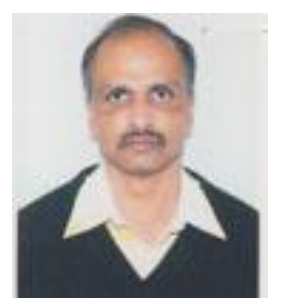

Dr Hirak Dasgupta is working as a Professor and Director in Balaji Institute of Modern Management, Pune. Dr Hirak Dasgupta has completed his PhD in Management studies from Himachal Pradesh University, Shimla (Himachal Pradesh) in 2010. He has about 11 publications in peer reviewed national and international journals and has worked as referee for several international journals. His current areas of interest are modeling in Marketing, Supply chain management and Human resource management.

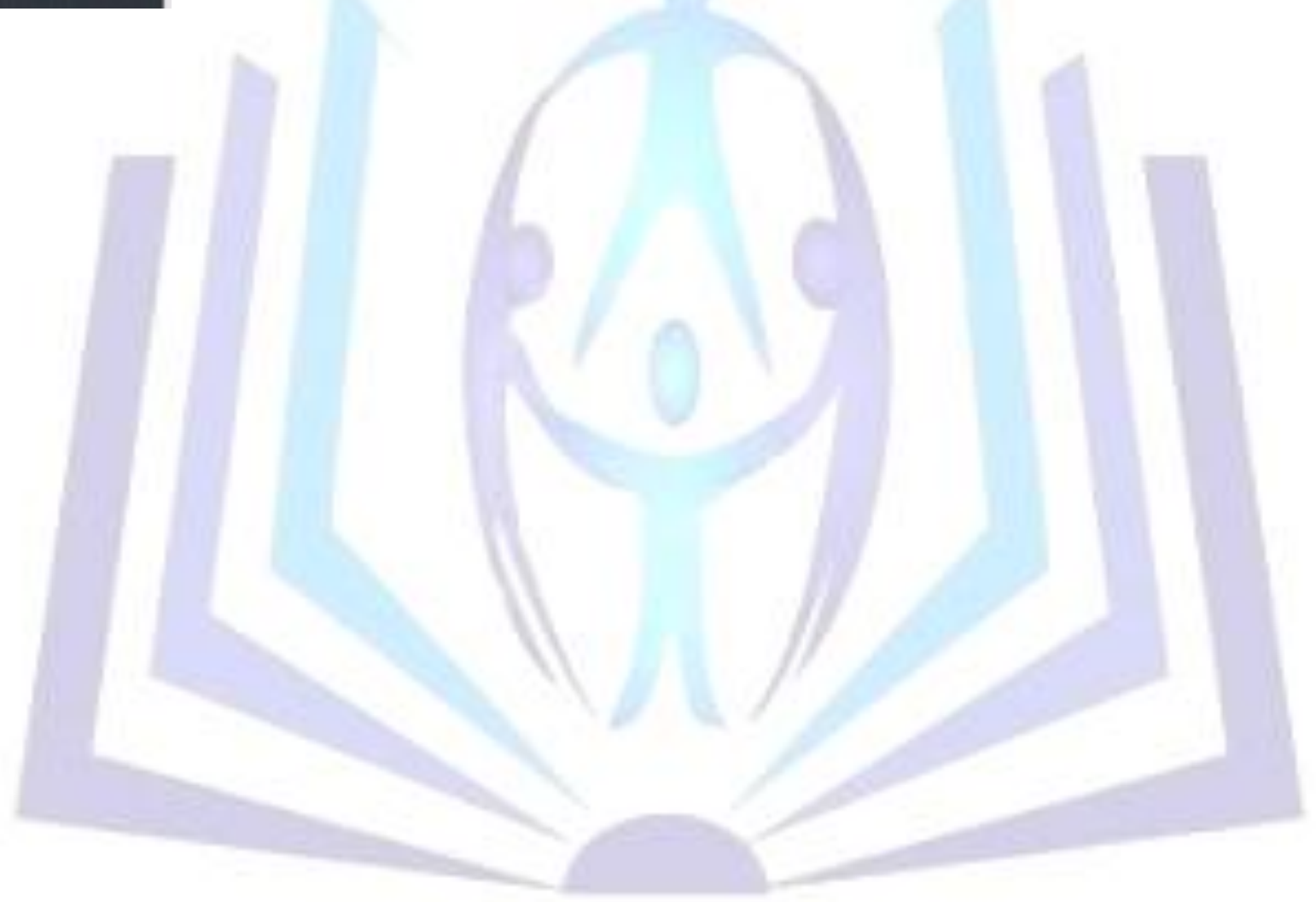

